JIPFRI, Vol. 5 No. 2

Halaman: 72 - 79

November 2021
JIPFRI (Jurnal Inovasi Pendidikan Fisika dan Riset IImiah)

https://doi.org/10.30599/jipfri.v5i2.1117

\title{
Sistem Pemantauan Gas Benzena dengan Aplikasi Blynk
}

\author{
Fitria Hidayanti ${ }^{1^{\star}}$, Kiki Rezki Lestari ${ }^{2}$, dan Donni Indra Kusumo ${ }^{3}$ \\ 1,2,3 Program Studi Teknik Fisika, Universitas Nasional \\ Jalan Sawo Manila No. 61, Pejatan, Pasar Minggu 12520 \\ *E-mail: fitriahidayanti@gmail.com
}

\begin{abstract}
Abstrak
Gas benzena merupakan bahan yang banyak digunakan di laboratorium sebagai pelarut. Dalam pemakaiannya, uap gas benzena dapat membahayakan bagi yang menggunakannya. Untuk itu, penelitian ini bertujuan untuk mengukur dan memantau kadar gas benzena dengan platform Internet of Things (IoT) sebagai sistem monitor dan notifikasi di perangkat smartphone android. Sensor yang digunakan adalah MS1100 untuk mendeteksi gas benzena dan mengirimkan sinyal input. Sinyal ini kemudian diproses oleh mikrokontroler NodeMCU. Modul wifi yang terdapat pada NodeMCU ini mengirimkan nilai yang terbaca pada sensor ke platform loT Blynk untuk ditampilkan dalam bentuk grafik. Nilai ini diproses sesuai dengan program dan jika memenuhi nilai setpoint yang ditentukan maka sistem memberikan notifikasi kepada pengguna melalui aplikasi Blynk di perangkat smartphone android serta mengaktifkan buzzer dan exhaust fan di dalam ruang laboratorium. Dari hasil implementasi pemantauan gas benzena diperoleh nilai rata-rata kandungan gas benzena di laboratorium sebesar 0,17 ppm.
\end{abstract}

Kata kunci: Sistem pemantauan, gas benzena, blynk, NodeMCU, IoT

\begin{abstract}
Benzene gas is a material widely used in the laboratory as a solvent. Benzene gas can be harmful to people. Therefore, this study aims to measure and monitor benzene gas levels with the Internet of Things (IoT) platform as a monitoring and notification system on android smartphone devices. The sensor used is MS 1100 to detect benzene gas and transmit input signals. The NodeMCU microcontroller processes these signals. This wifi module in NodeMCU sends the sensor's value to the Blynk loT platform to display in graph form. This value is processed under the program and it meets the setpoint then the system provides notifications to users through the Blynk application on android smartphone devices as well as activating buzzer and exhaust fans in the laboratory room. The result showed that monitoring of benzene gas in the laboratory as $0.17 \mathrm{ppm}$.
\end{abstract}

Keywords: Monitoring system, benzene gas, blynk, NodeMCU, IOT

\section{PENDAHULUAN}

Gas benzena merupakan pelarut yang sering digunakan dalam laboratorium. Penggunaan gas benzena harus secara hatihati karena gas benzena bersifat karsinogen bagi tubuh manusia. Dampak yang diakibatkan dari paparan gas benzena dapat bersifat akut dan kronis. Pada tingkat akut dapat menyebabkan kematian, sedangkan pada tingkat kronis dapat menyebabkan leukemia. Untuk itu, dalam SNI 19-0232-2005 (Indonesia, S. N., 2005) ditetapkan nilai ambang batas (NAB) untuk gas benzena sebesar $10 \mathrm{ppm}$.
Dalam
ini, digunakan

beberapa device dan aplikasi yaitu sensor gas MS1100, nodeMCU ESP 8266, LCD, buzzer, modul relay, exhaust fan, Arduino IDE dan aplikasi Blynk.

Sensor gas MS1100 (Xu-hua, 2014). Sensor ini merupakan sensor yang dapat mendeteksi gas seperti benzena, toluena dan formaldehida. Prinsip kerjanya adalah dengan menerima perubahan nilai resistansi (analog) pada pin keluaran saat terkena gas (Ye \& Chen, 2011). Dalam penggunaannya, harus diketahui nilai sensitivitas terhadap gas yang ingin diukur atau hubungan tegangan keluaran sensor terhadap nilai konsentrasi gas yang akan diukur dalam satuan ppm.

NodeMCU ESP 8266 Lolin (Suryana, 
2021) merupakan open source Internet of Things (IoT) board yang berbasis Firmware eLua untuk membuat simulator produk loT dengan memakai Arduino IDE serta memiliki systems on a chip (SoC) ESP 8266 (Saputra, 2019) yang mengintegerasikan GPIO, Pulse Width Modulation (PWM), IIC, 1-Wire, dan Analog to Digital Converter (ADC) serta dilengkapi dengan fitur wifi dalam satu board.

LCD merupakan komponen elektronik yang berfungsi sebagai tampilan suatu data, baik karakter, huruf maupun grafik. Berdasarkan jenis tampilan, LCD terdiri atas segment LCD, Dot Matrix character LCD, dan Graphic LCD. Pada studi ini digunakan Dot Matrix character LCD dengan kombinasi karakter 20x4 (Djatmiko, 2016).

Buzzer merupakan komponen elektronik yang berfungsi untuk mengubah getaran listrik menjadi getaran suara. Buzzer biasanya digunakan sebagai indikator bahwa proses telah selesai atau pada kondisi tertentu seperti alarm (Lawate \& Ali, 2014).

Modul relay (Sahtyawan \& Wicaksono, 2020) merupakan saklar yang dioperasikan secara elektrik yang memungkinkan untuk menghidupkan atau mematikan sirkuit dengan menggunakan voltase atau arus yang jauh lebih tinggi dari pada yang dapat ditangani oleh mikrokontroler. Pada modul relay terdapat 3 koneksi yaitu Normally Close (NC), COM, dan Normally Open (NO) dimana jenis kontak yang digunakan pada perangkat ini adalah NO (Wicaksono, 2017).

Exhaust Fan adalah sebuah alat untuk menyedot atau menyaring udara yang tidak kita inginkan supaya keluar, seperti udara sisa pembakaran atau gas dari suatu ruangan. Proses kerjanya dengan memiliki lekukan kipas yang mengarah keluar maka saat beroperasi akan mengeluarkan udara dari dalam (Hrica, Chatterjee \& TamizhMani, 2011).

Arduino Integrated Development Environment (IDE) adalah software arduino yang digunakan untuk membuat rancangan atau program khusus pada mikrokontroler Arduino (Fezari \& Al Dahoud, 2018).

Blynk adalah Platform IoT untuk perangkat iPhone Operating System (iOS) dan Android yang dapat mengontrol Arduino,
Raspberry Pi dan ESP8266 sejenisnya melalui internet (Waworundeng \& Lengkong, 2018). Blynk memiliki 3 komponen utama yaitu aplikasi untuk membuat project, server untuk komunikasi antara smartphone dengan server, dan libraries yang mendukung pembuatan suatu sketch pada software seperti arduino IDE.

Gas benzena banyak digunakan sebagai pelarut di laboratorium, namun gas benzena merupakan zat kimia yang tergolong dalam bahan beracun dan berbahaya (B3) karena bersifat karsinogenik pada tubuh manusia. Sayangnya, sistem pemantauan kadar gas benzena di laboratorium berbasis smartphone android dengan platform loT masih belum maksimal dilakukan. Oleh karena itu, penelitian ini bertujuan untuk merancang, membuat dan menguji alat pemantau gas benzena dengan aplikasi Blynk untuk mengukur dan mengetahui kandungan gas benzena yang ada di laboratorium sesuai dengan SNI 19-0232-2005 tentang nilai ambang batas (NAB) zat kimia di udara tempat kerja.

\section{METODE/EKSPERIMEN}

Diagram alir dalam studi ini dapat dilihat pada Gambar 1 .

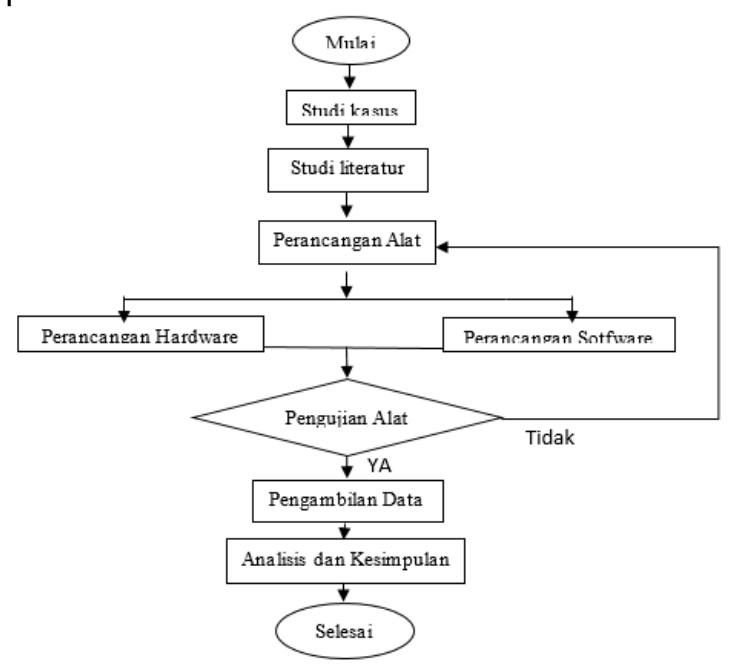

Gambar 1. Diagram Alir Penelitian

Pada Gambar 2 dijelaskan blok diagram dari sistem pemantauan yang dibuat. Hasil Pembacaan pada sensor MS1100 akan diolah ke dalam program pada NodeMCU sehingga menghasilkan nilai ppm dari kadar gas benzena 
yang dideteksi. Kemudian nilai tersebut akan di kirimkan ke LCD untuk ditampilkan. Selain mengirimkan data ke LCD, data juga di kirim ke Blynk melalui jaringan internet agar dapat dipantau juga menggunakan smartphone android dari lokasi berbeda. Nilai yang telah terukur dan diolah di dalam NodeMCU juga menjadi parameter untuk mengaktifkan buzzer dan exhaust fan.

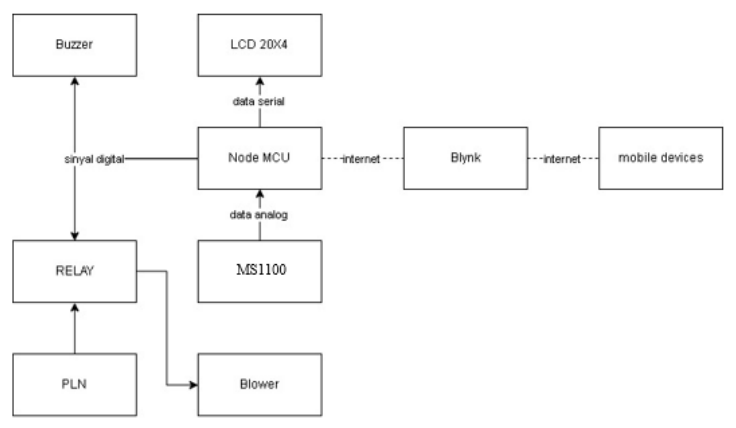

Gambar 2. Blok Diagram Sistem Pemantauan

Untuk skematik dari rangkaian hardware secara keseluruhan sebagaimana ditunjukan pada Gambar 3.

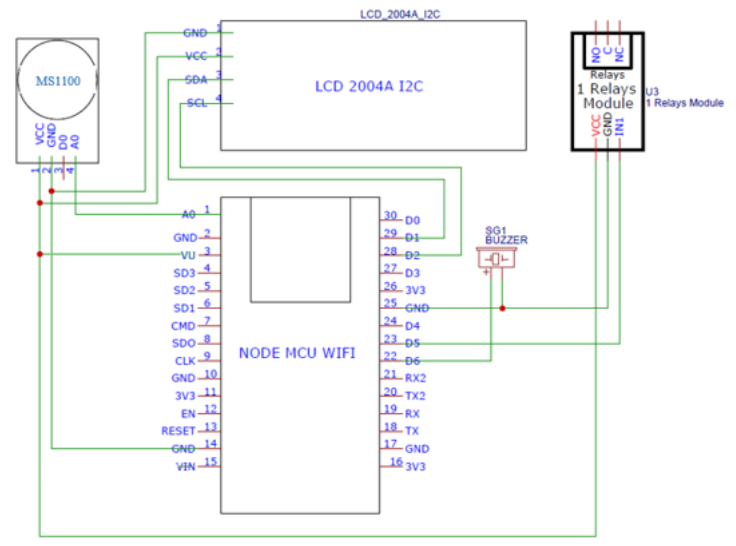

Gambar 3. Skematik Rangkaian Hardware

Desain alat pemantau gas benzena yang dibuat ditunjukan pada Gambar 4.
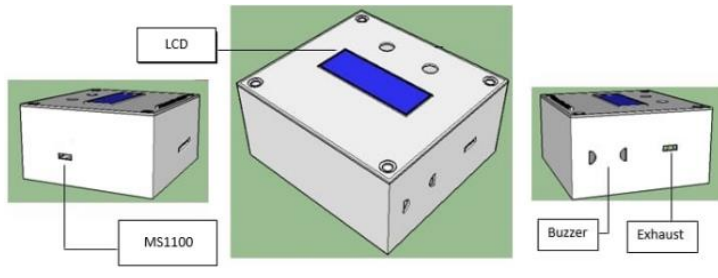

Gambar 4. Desain Alat Pemantauan Gas Benzena
Sensor MS1100 digunakan untuk mendeteksi kadar gas benzena dengan satuan ppm. Untuk itu perlu diketahui hubungan tegangan keluaran sensor terhadap konsentrasi (ppm) yang diperoleh dari pengujian menggunakan gas chromatography untuk pembacaan gas benzena. Dari hasil pengujian diperoleh data pada Tabel 1 .

Tabel 1. Hubungan Konsentrasi Gas dan Tegangan Sensor

\begin{tabular}{cccc}
\hline $\begin{array}{c}\text { Volume } \\
\text { Benzena } \\
(\mathrm{mL})\end{array}$ & $\begin{array}{c}\text { Waktu } \\
(\text { menit })\end{array}$ & $\begin{array}{c}\text { Konsentrasi } \\
\text { Gas } \\
\text { Benzena } \\
(\mathrm{ppm})\end{array}$ & $\begin{array}{c}\text { Tegangan } \\
\text { Sensor } \\
(\text { Volt })\end{array}$ \\
\hline 20 & 40 & 0,25309 & 1,22 \\
\hline 40 & 40 & 1,33297 & 1,33 \\
\hline 60 & 40 & 2,82951 & 1,41 \\
\hline 80 & 40 & 4,21544 & 1,50 \\
\hline 100 & 40 & 5,37672 & 1,56 \\
\hline 120 & 40 & 6,45206 & 1,62 \\
\hline
\end{tabular}

Setelah diperoleh data sebagaimana yang ditunjukkan pada Tabel 1, selanjutnya untuk menghubungkan tegangan keluaran sensor terhadap nilai konsentrasi (ppm) digunakan pendekatan persamaan garis yang diperoleh dari grafik hubungan konsentrasi gas dan tegangan sensor MS1100 untuk pengukuran gas benzena sebagaimana yang ditunjukkan pada Gambar 5.

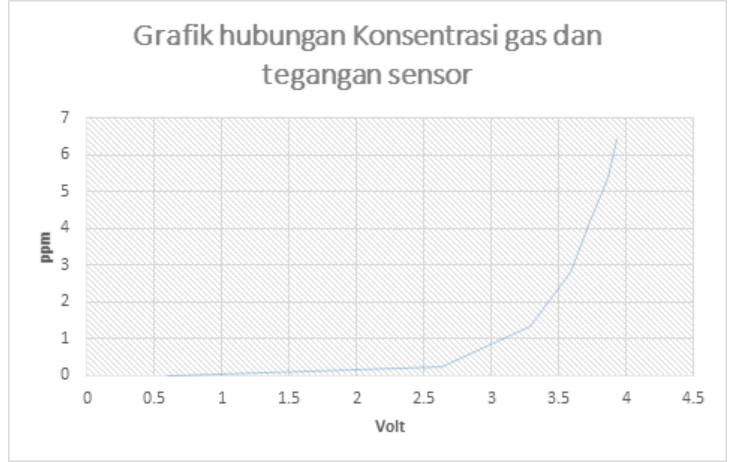

\section{Gambar 5 Grafik Hubungan Konsentrasi Gas} dan Tegangan Keluaran Sensor MS100

Dari Gambar 5 diperoleh persamaan garis untuk menentukan nilai konsentrasi (ppm) dari pembacaan sensor yaitu:

$Y=10^{-4} \cdot X^{8.0666}$ 
Dimana nilai $Y$ adalah konsentasi (ppm) dan $X$ adalah tegangan keluaran, $V_{\text {out }}$ (Volt). Selanjutnya dengan memasukan persamaan (1) beserta nilai yang diperlukan ke dalam pemograman maka diperoleh nilai konsentrasi (ppm) dari hasil pengukuran sensor MS1100.

Setelah perancangan dan pembuatan selesai dilakukan beberapa pengujian yakni pengujian alat, pengujian kontrol buzzer, exhaust fan, dan implementasi alat.

\section{HASIL DAN PEMBAHASAN}

\section{Pengujian Alat Pemantau Gas Benzena}

Pengujian dilakukan untuk mengetahui nilai error dan kinerja dari alat yang dibuat dengan cara membandingkan penunjukan nilai hasil pengukuran dari alat uji dan alat standar. Alat standar yang digunakan adalah Shimadzu Gas Chromatograph System GC-2010 Series. Proses pengujian sebagaimana ditunjukkan pada Gambar 6.

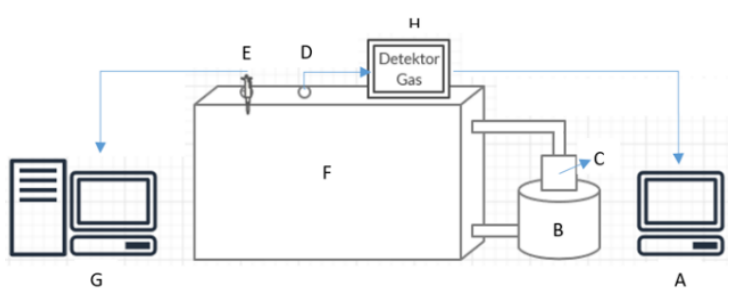

Gambar 6. Skema Pengujian Alat

Keterangan :

A. Komputer

B. Wadah Benzena

C. Fan

D. Sensor MS1100

E. Charcoal tube

F. Box Pengujian

G. Gas Chromatograph

H. Alat uji/Detektor Gas Benzena

Berdasarkan hasil pengujian alat sebagaimana yang telah dijelaskan, maka diperoleh data pada Tabel 2 .

Tabel 2 Hasil Pengujian Alat

\begin{tabular}{cccc}
\hline $\begin{array}{c}\text { Volume } \\
\text { Benzena } \\
(\mathrm{mL})\end{array}$ & $\begin{array}{c}\text { Durasi } \\
\text { (menit) }\end{array}$ & $\begin{array}{c}\text { Penunjukan } \\
\text { Alat Uji } \\
(\mathrm{ppm})\end{array}$ & $\begin{array}{c}\text { Penunjukan } \\
\mathrm{GC}(\mathrm{ppm})\end{array}$ \\
\hline 20 & 40 & 0,28 & 0,25 \\
\hline
\end{tabular}

\begin{tabular}{cccc}
\hline $\begin{array}{c}\text { Volume } \\
\begin{array}{c}\text { Benzena } \\
(\mathrm{mL})\end{array}\end{array}$ & $\begin{array}{c}\text { Durasi } \\
\text { (menit) }\end{array}$ & $\begin{array}{c}\text { Penunjukan } \\
\text { Alat Uji } \\
(\mathrm{ppm})\end{array}$ & $\begin{array}{c}\text { Penunjukan } \\
\mathrm{GC}(\mathrm{ppm})\end{array}$ \\
\hline 40 & 40 & 1,44 & 1,32 \\
\hline 60 & 40 & 3,09 & 2,83 \\
\hline 80 & 40 & 4,52 & 4,21 \\
\hline 100 & 40 & 5,65 & 5,37 \\
\hline 120 & 40 & 6,98 & 6,44 \\
\hline
\end{tabular}

Berdasarkan hasil percobaan sebagaimana ditunjukkan pada Tabel 2, diketahui nilai kesalahan sebesar $8,30 \%$ dan hubungan antara jumlah cairan benzena dengan gas terukur adalah linier. Nilai error tersebut masih berada di bawah batas kesalahan alat berdasarkan Operational Qualification pada Gas Chromatograph System yaitu $<10 \%$

Selanjutnya dilakukan pengujian alat dengan memindahkan posisi sensor sejauh 10 $\mathrm{cm}$ terhadap charcoal tube untuk mengetahui pengaruh jarak terhadap hasil pengukuran dari alat. Berikut adalah data hasil pengujian pengaruh jarak terhadap hasil pengukuran dari alat sebagaimana ditunjukkan pada Tabel 3 .

Tabel 3 Hasil Pengujian Pengaruh Jarak

\begin{tabular}{cccc}
\hline $\begin{array}{c}\text { Volume } \\
\begin{array}{c}\text { Benzena } \\
(\mathrm{mL})\end{array}\end{array}$ & $\begin{array}{c}\text { Durasi } \\
\text { (menit) }\end{array}$ & $\begin{array}{c}\text { Penunjukan } \\
\text { Alat Uji } \\
(\mathrm{ppm})\end{array}$ & $\begin{array}{c}\text { Penunjukan } \\
\text { GC (ppm) }\end{array}$ \\
\hline 20 & 40 & 0,29 & 0,25 \\
\hline 40 & 40 & 1,45 & 1,33 \\
\hline 60 & 40 & 3,13 & 2,83 \\
\hline 80 & 40 & 4,56 & 4,22 \\
\hline 100 & 40 & 5,80 & 5,38 \\
\hline 120 & 40 & 7,10 & 6,45 \\
\hline
\end{tabular}

Berdasarkan hasil percobaan pada Tabel 3 diketahui nilai kesalahan sebesar 10,01\% yang berarti bahwa jarak pada sensor terhadap sumber gas, mempengaruhi jumlah gas yang terukur. Adapun faktor yang menyebabkan nilai error pada pengujian alat di atas adalah karateristik dari sensor gas yang mampu melakukan sensing lebih dari satu jenis gas sehingga dimungkinkan terdapat gas lain yg ikut terukur. Hasil pengukuran dari gas chromatography merupakan nilai kadar gas benzena yang terserap pada charcoal sebagai media untuk sampling udara, sedangkan pada 
alat uji hasil pengukurannya merupakan kadar gas benzena yang diukur pada udara secara langsung sehingga dari hasil pengujian dapat dianalisis bahwa alat berfungsi dan dapat dipergunakan untuk mengukur kadar kandungan gas benzena di udara dengan nilai akurasinya $91,7 \%$.

\section{Pengujian Kontrol Buzzer dan Exhaust Fan}

Sistem Kontrol pada exhaust fan dan buzzer dilakukan secara otomatis dengan menggunakan nilai konsentasi gas (ppm) sebagai setpoint untuk mengaktifkan dan menonaktifkan exhaust fan dan buzzer. Setpoint konsentrasi gas diatur pada lima titik uji yaitu 0,1 ppm, 0,2 ppm, 0,3 ppm, 0,4 ppm dan $0,5 \mathrm{ppm}$. Hasil pengujian kontrol buzzer sebagaimana ditunjukan pada Tabel 4 .

Tabel 4. Hasil Pengujian Kontrol Buzzer

\begin{tabular}{cccc}
\hline $\begin{array}{c}\text { Konsentrasi } \\
\text { Gas } \\
\text { Benzena } \\
(\mathrm{ppm})\end{array}$ & \multicolumn{2}{c}{ Kondisi Buzzer } & Keterangan \\
\cline { 2 - 3 } & $\begin{array}{c}\text { Tidak } \\
\text { Aktif }\end{array}$ & Aktif & \\
\hline$\geqslant 0,1$ & & $\sqrt{ }$ & \\
\hline$\geqslant 0,2$ & & $\sqrt{ }$ & berfungsi \\
\hline$\geqslant 0,3$ & & $\sqrt{ }$ & berfungsi \\
\hline$\geqslant 0,4$ & & $\sqrt{ }$ & berfungsi \\
\hline$\geqslant 0,5$ & & $\sqrt{ }$ & berfungsi \\
\hline
\end{tabular}

Dari Tabel 4 diketahui sistem kontrol otomatis pada buzzer berfungsi dengan baik dan bunyi yang dihasilkan mampu terdengar di ruang laboratorium dan area basemant seluas $\pm 174 \mathrm{~m}^{2}$ pada gedung UP Metrologi.

Pada pengujian kontrol exhaust fan di lakukan juga pengujian terhadap respon waktu (delay) dari sistem kontrol exhaust fan. Untuk pengujian delay digunakan stopwatch sebagai standar perhitungan waktu. Hasil Pengujian ditunjukkan pada Tabel 5.

Tabel 5. Hasil Kontrol Exhaust Fan

\begin{tabular}{|c|c|c|c|c|}
\hline \multirow{2}{*}{$\begin{array}{c}\text { Konsentrasi } \\
\text { Gas } \\
\text { Benzena } \\
(\mathrm{ppm})\end{array}$} & \multicolumn{2}{|c|}{ Kondisi Buzzer } & \multirow{2}{*}{$\begin{array}{l}\text { Waktu } \\
\text { (detik) }\end{array}$} & \multirow[t]{2}{*}{ Keterangan } \\
\hline & $\begin{array}{c}\text { Tidak } \\
\text { Aktif }\end{array}$ & Aktif & & \\
\hline$\geqslant 0,1$ & & $\sqrt{ }$ & 2,03 & berfungsi \\
\hline$\geqslant 0,2$ & & $\sqrt{ }$ & 2,04 & berfungsi \\
\hline
\end{tabular}

\begin{tabular}{|c|c|c|c|}
\hline$\geqslant 0,3$ & $\sqrt{ }$ & 2,03 & berfungsi \\
\hline$\geqslant 0,4$ & $\sqrt{ }$ & 2,02 & berfungsi \\
\hline$\geqslant 0,5$ & $\sqrt{ }$ & 2,02 & berfungsi \\
\hline
\end{tabular}
sistem kontrol exhaut fan secara otomatis berfungsi dengan baik, dengan waktu respon saat posisi tidak aktif ke aktif \pm 2.02 detik.

\section{Hasil Implementasi}

Implementasi alat monitoring gas benzena dilakukan dengan menempatkan alat pada meja kerja dengan jarak $\pm 50 \mathrm{~cm}$ dari posisi petugas laboratorium. Sedangkan untuk posisi exhaust fan diletakkan di plafon dengan jarak \pm 4 meter dari posisi petugas laboratorium. Hasil pemasangan alat sebagaimana ditunjukkan pada Gambar 7.

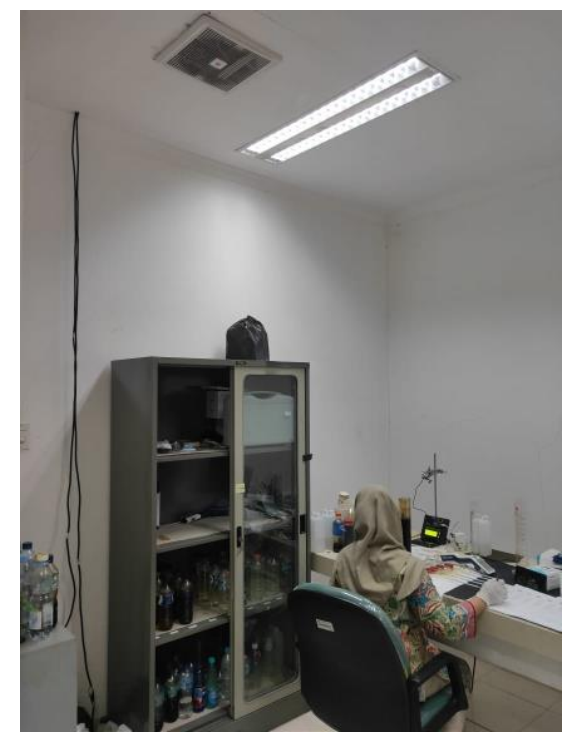

\section{Gambar 7 Hasil Pemasangan Alat Monitoring} Gas Benzena

Untuk tampilan hasil monitoring pada LCD dan smartphone android ditunjukkan pada Gambar 8.

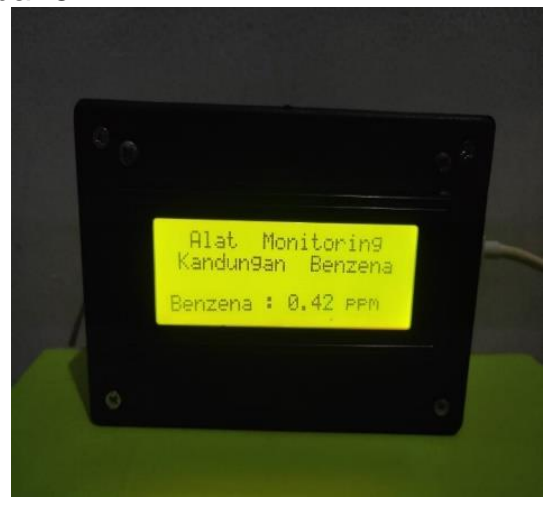

(A) 


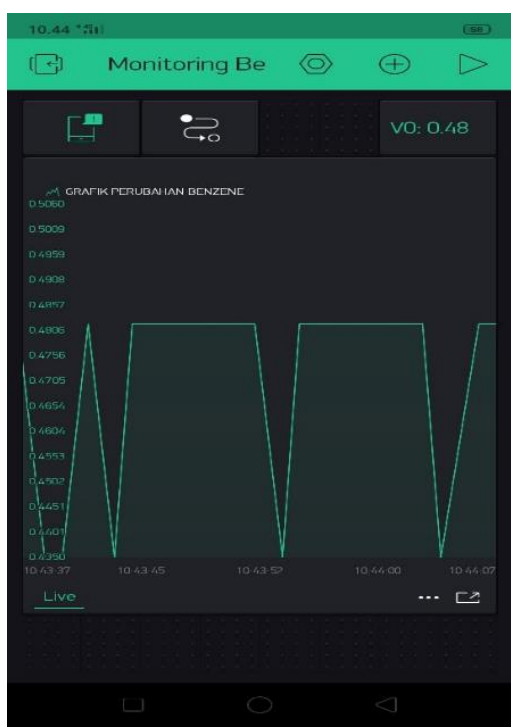

(B)

Gambar 8. Tampilan Monitor Gas melalui (A) LCD dan (B) Tampilan Monitor Gas melalui smartphone

Tampilan notifikasi pada smartphone android ditunjukkan pada Gambar 9.

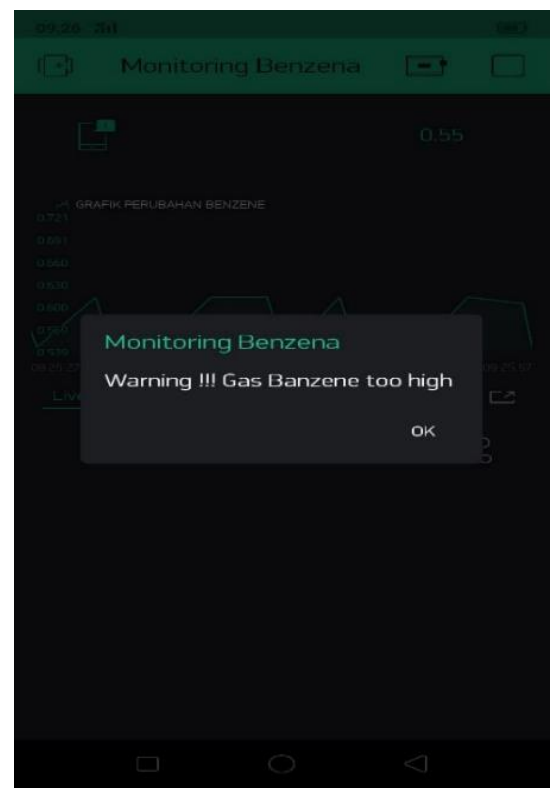

(A)

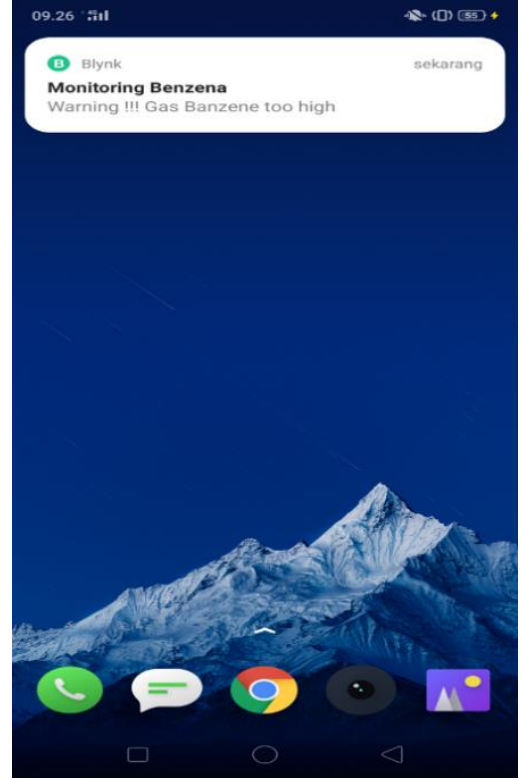

(B)

Gambar 9. (A) Tampilan Notifikasi saat Aplikasi Blynk sedang dibuka dan (B) Tampilan Notifikasi saat Aplikasi Blynk ditutup

Untuk data hasil pengukuran yang terdapat pada aplikasi blynk, juga dapat dikirimkan ke email pengguna melalui menu export data dalam format .csv yang dapat dibuka pada aplikasi excel di komputer.

Data hasil implementasi alat pemantauan gas benzena diambil dari pukul 09.00 s.d. 15.00 dengan waktu pencatatan permenit selama 6 hari. Namun karena banyaknya data sehingga data yang ditampilkan hanya berupa rekap data hasil implementasi sebagaimana ditunjukkan pada Tabel 6.

Tabel 6. Data Hasil Implementasi Alat Pemantauan Gas Benzena

\begin{tabular}{ccccc}
\hline Konsen- & \multicolumn{2}{c}{ Kondisi } & \multicolumn{2}{c}{ Pemantauan } \\
\cline { 2 - 5 } $\begin{array}{c}\text { trasi Gas } \\
\text { Benzena } \\
(\mathrm{ppm})\end{array}$ & Buzzer & $\begin{array}{c}\text { Exhaust } \\
\text { Fan }\end{array}$ & $L C D$ & $\begin{array}{c}\text { Smart } \\
\text { phone }\end{array}$ \\
\hline 0,18 & berfungsi & berfungsi & berfungsi & berfungsi \\
\hline 0,18 & berfungsi & berfungsi & berfungsi & berfungsi \\
\hline 0,15 & berfungsi & berfungsi & berfungsi & berfungsi \\
\hline 0,17 & berfungsi & berfungsi & berfungsi & berfungsi \\
\hline 0,18 & berfungsi & berfungsi & berfungsi & berfungsi \\
\hline 0,16 & berfungsi & berfungsi & berfungsi & berfungsi \\
\hline
\end{tabular}


Dari hasil implementasi yang ditunjukkan pada Tabel 4. dapat diketahui bahwa tidak setiap waktu alat pemantauan gas benzena menunjukan hasil pengukuran yang sama, hal ini dipengaruhi oleh jumlah aktivitas penggunaan cairan benzena di dalam laboratorium berdasarkan grafik pemantauan gas benzena sebagaimana yang ditunjukkan pada Gambar 10.

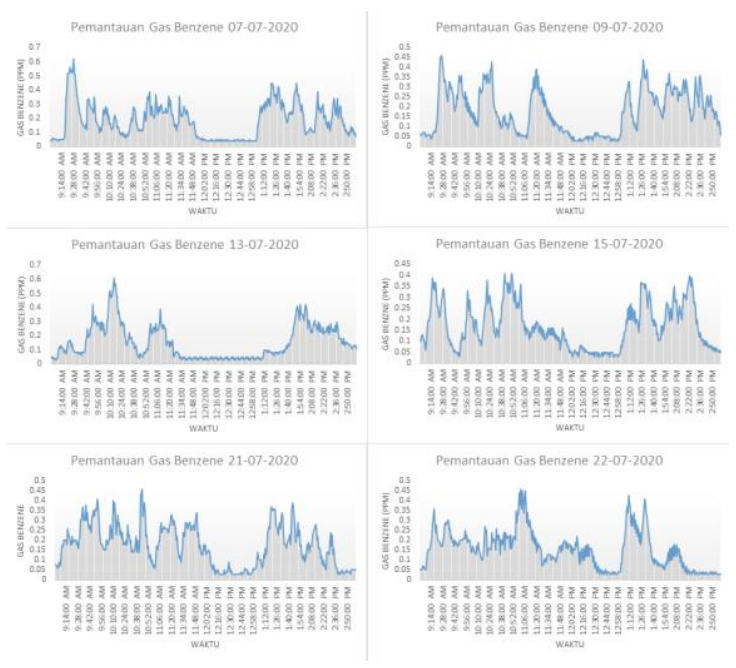

Gambar 10. Grafik Pemantauan Gas Benzena

Diketahui jumlah aktivitas penggunaan cairan benzena paling sering pada pukul 09.00 s.d. 11.00 dan pukul 13.00 s.d. 14.00 WIB serta paling sedikit pada pukul 12.00 s.d. 13.00 WIB. Dari hasil pengujian alat secara keseluruhan dapat dianalisis bahwa alat pemantauan gas benzena yang dibuat dapat diimplementasikan pada ruang laboratorium karena mampu mendeteksi, mengukur, dan memonitor kandungan gas benzena di dalam ruangan secara real time, memberikan notifikasi melalui smartphone, dan memberi peringatan melalui alarm/buzzer serta mengaktifkan exhaust fan untuk mengeluarkan udara dari ruangan.

Selanjutnya berdasarkan hasil penunjukan data pada Tabel 4 diketahui pula pada kondisi tersebut terdapat aktivitas di dalam laboratorium dengan nilai kandungan gas benzena sebesar 0,17 ppm, sehingga dapat dianalisis bahwa nilai kandungan gas benzena di ruang laboratorium UP Metrologi masih dibawah NAB yang ditetapkan berdasarkan SNI 19-0232-2005 tentang Nilai
Ambang Batas Zat Kimia di Udara Tempat Kerja.

\section{PENUTUP}

Pada penelitian ini didapatkan beberapa kesimpulan yaitu:

1. Pada penelitian ini telah berhasil dirancang dan dibuat alat pemantauan gas benzena menggunakan mikrokontroler NodeMCU dengan sensor MS1100 berbasis platfoam loT Blynk, yang mampu mengukur kadar gas benzena secara real time dan kontinu, juga dapat berfungsi untuk mengontrol buzzer dan exhaust fan, serta memantau dan memberikan notifikasi melalui perangkat smartphone apabila kadar gas benzena yang terdapat di ruangan melebihi nilai setpoint yang ditetapkan. Dengan nilai kesalahan yang diperoleh dari pengujian alat adalah 8,30\%.

2. Dari hasil Implementasi alat pemantau gas benzena diperoleh kesalahan kandungan gas benzena yang terdapat didalam ruang laboratorium pada Unit Pengelola Metrologi sebesar 0,17 ppm, dimana nilai tersebut masih berada dibawah NAB yang ditetapkan berdasarkan SNI 19-0232-2005 Tentang Nilai Ambang Batas Zat Kimia di Udara Tempat Kerja.

Saran untuk penelitian selanjutnya, hasil penelitian ini dapat digunakan sebagai salah satu bahan referensi untuk mengembangkan alat pemantauan gas khususnya jenis BTX (Benzena, Toluena, dan Xylena) secara bersamaan.

\section{UCAPAN TERIMAKASIH}

Terima kasih disampaikan kepada Lembaga Penelitian dan Pengabdian pada Masyarakat (LPPM) Universitas Nasional, Fakultas Teknik dan Sains, dan Program Studi Teknik Fisika yang telah mendukung penelitian ini.

\section{REFERENSI}

Djatmiko, W. (2016, October). Prototipe Sistem Pengukur Kualitas Tegangan Jala-Jala 
Listrik PIn. In PROSIDING SEMINAR

NASIONAL FISIKA (E-

JOURNAL) (Vol. 5, pp. SNF2016-CIP).

Fezari, M., \& Al Dahoud, A. (2018). Integrated Development Environment "IDE" For Arduino. WSN applications, 1-12.

Hrica, J., Chatterjee, S., \& TamizhMani, G. (2011, June). BAPV array: Thermal modeling and cooling effect of exhaust fan. In 2011 37th IEEE Photovoltaic Specialists Conference (pp. 003144003149). IEEE.

Indonesia, S. N. (2005). Nilai Ambang Batas (NAB) zat kimia di udara tempat kerja. Jakarta: Badan Standarisasi Nasional.

Lawate, S. V., \& Ali, M. S. (2014). Electronic eye for security system. International Journal of Electronic and Electrical Engineering, 7(9).

Sahtyawan, R., \& Wicaksono, A. I. (2020). Application for Control of Distance Lights Using Microcontroller Nodemcu Esp 8266 Based on Internet of Things (IoT). vol, 3839, 43-50.

Saputra, I. (2019). Sistem Monitoring Brankas Berbasis Web Menggunakan Nodemcu Esp8266 V. 3 (Doctoral dissertation, STMIK AKAKOM YOGYAKARTA).

Suryana, T. (2021). Implementasi Komunikasi Web Server Nodemcu Esp8266 Dan Web Server Apache Mysql Untuk Otomatisasi Dan Kontrol Peralatan Elektronik Jarak Jauh Via Internet.

Waworundeng, J. M., \& Lengkong, O. (2018). Sistem Monitoring dan Notifikasi Kualitas Udara dalam Ruangan dengan Platform loT. Cogito Smart Journal, 4(1), 94-103.

Wicaksono, M. F. (2017). Implementasi modul wifi NodeMCU Esp8266 untuk smart home. Komputika: Jurnal Sistem Komputer, 6(1).
YE, L. N., \& CHEN, L. (2011). Hardware Design of Toxic and Harmful Gas Monitoring System Based on ZigBee Wireless Sensor Network. Journal of Jilin Teachers Institute of Engineering and Technology, 02.

Xu-hua, L. I. (2014). Formaldehyde Gas Monitoring Design Based on Wi-Fi Network. Journal of Jiaying University, 11. 